\title{
Nursing theories in professional training and practice: perception of postgraduate nursing students
}

\author{
Teorias de enfermagem na formação e na prática profissional: percepção de pós-graduandos \\ de enfermagem
}

Maria de Fátima Garcia Lopes Merino ${ }^{1}$, Paloma Luana de Azevedo Ramos da Silva ${ }^{1}$, Maria Dalva de Barros de Carvalho $^{1}$, Sandra Marisa Pelloso ${ }^{1}$, Vanessa Denardi Antoniassi Baldissera ${ }^{1}$, Ieda Harumi Higarashi ${ }^{1}$

\begin{abstract}
Objective: to analyze the perception of postgraduate students about nursing theories in professional training and practice. Methods: it was a qualitative research with 22 students enrolled in the Theoretical Foundations of Nursing Care class of a postgraduate nursing course. Results: the lack of teaching of nursing theories at the undergraduate level and the need to insert this object of study in the curricula of the courses were verified, since they support and guide nurses' actions, corroborating the relationship between theory and practice. The theories conferred scientific thinking and added value to professional performance, ensuring quality and recognition to the profession. Conclusion: the contact with the theories in undergraduate studies is limited and resuming the thematic in postgraduation is indicated as opportune. In the perception of the postgraduate students, the knowledge on nursing theories allows professionals to extract their essence, scientifically strengthen their practice and, thus, recognize them as work guidelines.
\end{abstract}

Descriptors: Education, Higher; Education, Nursing, Graduate; Nursing Theory; Nursing Education Research.

Objetivo: analisar a percepção de pós-graduandos acerca das teorias de enfermagem na formação e na prática profissional. Métodos: pesquisa qualitativa, com 22 alunos matriculados na disciplina Fundamentos Teóricos do Cuidado em Enfermagem de um curso de pós-graduação em enfermagem. Resultados: evidenciaram-se a carência do ensino das teorias de enfermagem na graduação e a necessidade de inserção deste objeto de estudo nos currículos dos cursos, uma vez que elas sustentam e norteiam as ações do enfermeiro, respaldando a relação entre teoria e prática. As teorias conferiram pensamento científico e agregaram valor ao fazer profissional, assegurando qualidade e reconhecimento à profissão. Conclusão: o contato com as teorias na graduação é limitado, e a retomada da temática na pós-graduação é apontada como oportuna. Na percepção dos pósgraduandos, o conhecimento das teorias de enfermagem permite ao profissional extrair sua essência, fortalecer cientificamente sua prática e, assim, reconhecê-las como norteadoras do trabalho.

Descritores: Educação Superior; Educação de Pós-Graduação em Enfermagem; Teoria de Enfermagem; Pesquisa em Educação de Enfermagem.

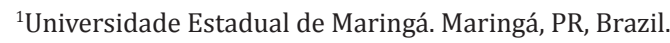




\section{Introduction}

Nursing has developed its praxis through the definition of knowledge based on theoretical and methodological references, which give it scientific visibility, particularly to transcend its technical essence. Epistemological contributions, aimed at determining the construction of knowledge and guide professional practice, demonstrate to professors and students how theoretical nursing models can guide critical thinking and decision making in this activity ${ }^{(1)}$.

In this context, over time, both theoretical formation and nursing practice began to demand concepts, values, beliefs, and knowledge from the different areas of knowledge, revealing their own theoretical models and developing concepts of men, environment, and nursing ${ }^{(1-2)}$ to be applied in assistance.

The path of knowledge, combining critical thinking and professional creativity, has enabled the development of nursing theories. Its relevance in the evolution of the profession consisted in distancing itself from the empirical aspect to adopt the professional practice based on scientific knowledge ${ }^{(2)}$. Thus, theories present proposals for assistance, revealing purposes and limitations, directing care relationships.

In this perspective, theories build parameters and assistance models for the professional performance. They are essential references in the disciplinary composition of the profession, given their relevance to the areas of teaching, research, and care practice. They allow to reveal the nuances and tendencies of this area of knowledge, emphasizing its importance as a discipline or cross-sectional content in undergraduate and postgraduate nursing courses ${ }^{(1-2)}$.

Studies that address the performance of nurses' activities based on a certain theory have already been conducted ${ }^{(3-5)}$; however, there is a lack of scientific production regarding theories in the nursing training process ${ }^{(6-7)}$. This gap is reinforced when considering that many studies on theories are researches of review, reflection of professionals, and applicability of a specific theory in nursing practice ${ }^{(6,8)}$.
Bearing in mind that the knowledge production in Brazil permeates all moments of professional training and is strongly focused on stricto sensu postgraduate courses, it reveals the importance of the presence of nursing models and theories in the training of postgraduate students ${ }^{(9-10)}$, in addition to the fact that the knowledge provided by the theories during professional training needs to enable nurses to rethink their practice and transform it through the theoretical basis. Therefore, seeking to contribute to the construction of transformative paradigms in nursing training, it is considered pertinent to incorporate theoretical models to the nursing educational practice.

For this purpose, this study presented the following research question: How do postgraduate students perceive the inclusion of nursing theories during the nursing training and, later, in their professional practice?

This study aimed to analyze the perception of postgraduate students on nursing theories in training and professional practice.

\section{Methods}

It was a qualitative study conducted through interview with students of the Theoretical Foundations of Nursing Care class of the postgraduate nursing program of a university in the Southern Region of Brazil. Study population comprised 22 of the 29 students enrolled in the course, with a sample formed from the data saturation principle.

The interview script included identification and sociodemographic characterization; closed questions regarding the training, performance, and professional experience of postgraduate students; and open questions, seeking to understand the subjects' experience and perception regarding nursing theories, their inclusion in the undergraduate curricular structure, and their contributions to professional practice. Interviews took place individually and privately, recorded and with an average duration of 50 minutes, preserving the anonymity of the interviewees. Data collec- 
tion occurred between June 2016 and March 2017.

Textual transcripts of the interviews were carried out by a single researcher, shortly after the event, to be as reliable as possible. Nonverbal communication observed during the interview was noted in the transcript as a comment. The identifiers were excluded from the transcripts, to ensure the anonymity of the subjects, who were named with the letter P and the interview number. Participants had access to the transcripts, to confirm their speeches, comment, or suggest changes.

For data analysis, the thematic categorical analysis was chosen ${ }^{(11)}$, a technique that includes ordering the transcription data; re-reading and organization of data; data classification after exhaustive reading or "deepening" on the speech and topic setting; and final analysis by understanding the whole process. Qualitative research was conducted and reported based on the consolidated criteria for reporting qualitative research (COREQ).

The study complied with the norms of Resolution 466/12 and was approved by the Ethics Committee in Research involving human beings of the Universidade Estadual de Maringá, under protocol № $1,616,045$.

\section{Results}

Of the participants, 21 were female (95.4\%), the majority were in the age group of 20 to 25 years (54.4\%), followed by the age group over 35 years (22.7\%). Recent graduates represented $36.4 \%$, and $63.6 \%$ had over four years of professional experience. Most postgraduate students (86.4\%) came from public universities, with all training institutions located in the Center-South Region of the country.

After analysis, the two categories designed were: "Nursing theories at the undergraduate and postgraduate levels: approach to the theme" and "Nursing theory: professional identification and contributions to the practice".

\section{Nursing theories at the undergraduate and post- graduate levels: approach to the theme}

In this category, postgraduate students recognized the need for valuing theories in the nursing training and the importance of including this object of study in the curricula of the courses: It is extremely important to insert theories in undergraduate and postgraduate studies. This knowledge provides support for nursing, gives greater insight into practice, directing care in principles that guide and organize the Nursing Process and professional action (P8). The theories build the scientific and structural basis that supports the practice through concepts, fundamentals, objectives, and contextualization. They refer to a science based on studies of researchers who dedicated their professional trajectory to understanding the needs of the human being, seeking to perfect and guide nursing care (P11).

In spite of this perception, the participants emphasized the little contact with the theories during the undergraduate course, revealing a timely resumption of the subject matter in the postgraduate course in progress, highlighting the possibility of a theoretical deepening on a theme up to then little explored by them, during their academic training: By better studying nursing theories, I perceive the importance of their inclusion in undergraduate curricula, since the students will have contact with different ways of assisting the individual and collectivity, providing a better care, holistic (P5). Now I see that nursing theories scientifically support the practice. Good training is required during undergraduate to provide professionals better prepared to work with the population, offering quality care and improving their health (P12).

It was verified that the identification of future nursing professionals with the theories that support the profession could be compromised by the deficient approach on the subject during their training: I have had brief and superficial contact with some theories in undergraduate studies. The greatest depth was given through this class, which allowed the identification of the scientific publications that focus on the different theories and fomented a more critical discussion about them (P9). During the undergraduate course, I do not remember having seen theories in more depth, but now I miss it (P1). The contact with nursing theories, before this postgraduate course, was minimal and superficial. I only had contact with Wanda Horta's theory at undergraduate level (P5). 


\section{Nursing theory: professional identification and contributions to the practice}

Based on the deepening of knowledge about this subject, postgraduate students were able to extract the essence of the theories and their value for the "professional performance", noting that they guide the nurses work and defining them as a support for the applicability of their actions: They give us a direction to work, thus facilitating nursing care (P1). Knowing the theories, we can recognize them in our practice, as nurses. We realize that each one has a specific object but complement each other in a more comprehensive care directing our work (P3).

Since one of the implications of nursing theories is to support professional practice, postgraduate students have recognized the possibility of drawing a parallel between them and their application in professional practice, which remains supported by the various theories: I believe Wanda Horta's theory is easier to implement in the daily routine at the hospital. Some theories are better for study or for a specific practice, but for daily use in the hospital I find this more appropriate (P14). Orem and the Self-Care Theory are more commonly used. Currently, with the increase of chronic diseases and rehabilitation techniques, patients need more attention for self-care (P8). I relate to Leininger and Orem. As my assistance takes place at home, self-care and knowing/respecting the culture of the other are important allies in the relationship with the individual, family, and community (P4).

The knowledge of nursing theories for postgraduate students also contributes to the organization of nursing services, promoting the development and implementation of the Nursing Care Systematization. Coordinated actions subsidize the performance of care, ensuring quality and recognition as a profession, with a body of knowledge: I consider the theories fundamental. Basing care in a theory qualifies the nurses' work process (P7). The knowledge of theories supports nursing, giving greater insight into practice, guiding care in scientific principles, leading to an organized care process (P9). We need this scientific foundation to apply it at work. It is a protection for nurses, a way to give visibility to the work, besides providing conditions for a systematized assistance (P21). The knowledge of the theories improves the care provided, organizes the care, and contributes to the patient's prognosis. These factors provide higher quality to my care (P12).

\section{Discussion}

The limitation of this research comprises the study location, which was carried out in a single teaching institution, thus preventing the generalization of the findings. Nonetheless, the results are considered valid, as they reflect similar conditions verified in larger surveys ${ }^{(3,6,12-13)}$.

The limited exposure of undergraduate students to nursing theories in nursing programs may limit their knowledge of the subject, hindering its incorporation into their learning, hence interfering in the development of their competencies ${ }^{(9,12)}$. Therefore, knowing the theories during training contributes to minimize a deficit in the theoretical understanding of nurses and allows to develop a coordinated thought in their actions, assisting in the professional practice ${ }^{(1)}$.

There were few studies found on the relevance of including the theories in the nursing training process, either as an object of study or as a training moment, to allow nurses to rethink their practice and transform it through a theoretical basis. In this perspective, the theme of this research, concerning the teaching of nursing theories in undergraduate and postgraduate courses, plays an important role in professional training, in the development of nursing practice, and in the care provided to the patients.

Analyses of the interviews enabled to extract some aspects to be decoded and discussed, based on previous studies on this topic.

Extreme ages were verified among postgraduate students, with "young" and recent graduates at the same level, in the postgraduate course, as "older" and more experienced professionals in the area. The decrease in the average age of students in stricto sensu postgraduate courses has been previously reported ${ }^{(14)}$, emphasizing that many students choose to 
enroll in these courses shortly after graduating, even without having previous professional experience in their area of training.

Regarding the training institutions of the participants, they were public and private education institutions, and their specific knowledge of nursing theories presented similarities. This data is endorsed by the National Curricular Guidelines for Undergraduate Courses, which determine similarities between curricula of different institutions. Nevertheless, even in accordance with the guidelines, there are different configurations of the curricula and their adaptation to the local reality of each institution, reflecting distinctive approaches in the choice of theories that subsidize the students' training ${ }^{(13)}$. It is noteworthy that the theoretical models used in the training of academics have undergone changes over the years, contributing to a greater formative plurality, regarding the use of nursing theories ${ }^{(1,9)}$.

As for the theme "Nursing theories at undergraduate and postgraduate levels: approach to the theme" for postgraduate students, nursing theories are extremely relevant to subsidize the profession and should contribute to guide the professional practice, besides recognizing that the primary purpose of nursing knowledge is to enrich its practice. In their narratives, it was observed the importance they give to the teaching of theories as scientific contribution to their actions. This perception of the participants is in line with the results of other studies, with this research as a motto ${ }^{(4,5,13)}$.

All participants reported that, even if only superficially, at some point in their professional training, they had contact with at least one nursing theory.

These are relevant statements, considering that nursing theories provide the student with support for the practice and facilitate the knowledge of the scientific roots of the profession. Its introduction, from the undergraduate level, should give deepening on nursing and its theoretical concepts, with continuity throughout their formation ${ }^{(9,14)}$. The theories and their possibilities of implementation, in the view of under- graduate students, are the reason that distinguish one discipline from another and clarify the assumptions and values that guide and define the nature of practice ${ }^{(2)}$, reaffirming their contribution to professional development. Previous studies ${ }^{(9,12)}$ demonstrated that most of the students interviewed considered the teaching of theories in the undergraduate course appropriate to the professional practice, improving the quality of care.

Although postgraduate students have raised questions about the lack of this approach in the institutions responsible for their professional training, they also emphasized the importance of a more in-depth focus on theories at the postgraduate level, highlighting the importance of resuming the subject for nurses, fostering the construction of scientific knowledge.

From the start of undergraduate courses, the teaching of nursing theories, research, and practice has been superficial, not always being presented in its entirety to the students, which can result in a decrease in their importance for future nursing professionals $^{(9,15)}$.

The observation that nursing students' knowledge of theories is vague has also been evidenced in previous studies $(9,12,16)$, thus demonstrating a partial incorporation or absence of the use of conceptual theories or models in their professional actions. Moreover, students showed that, due to the weakening of approaches on theories in the curricular bases of the courses, professors face challenges in sharing with the students values and beliefs pertinent to the profession, risking that what constitutes the science of nursing might be lost and that its unique contributions to the profession are overshadowed ${ }^{(17)}$.

Furthermore, in this perspective, there is a risk of placing theories in less important conditions, making the students' knowledge deficient in terms of theoretical and conceptual understanding of nursing ${ }^{(9)}$. Nevertheless, there was a positive response from academics when presenting theoretical models and their association with practice, as performed in 
other studies ${ }^{(9,12)}$. In this condition, as knowers of their metaparadigms, students understand their importance and, as a knowledge-based professional, become better able to choose the most appropriate theory to the care process ${ }^{(2)}$.

Regarding the category "Nursing theory: professional identification and contributions to the practice", questions were reported concerning the relationship between the knowledge of the postgraduate students about the theories and their application in professional experience.

Participants understand that nursing theories subsidize the care promotion, leading the professional's action to the patient as a complete being, living in society, with habits and customs of their own. Supported by scientific knowledge, nurses can provide them with qualified and directed care, respecting individual aspects.

Given its characteristics, nursing theories develop concepts, models, and assumptions applicable in practice and that facilitate professional activities, justifying the importance of supporting daily care in theories that have applicability, assist the population, and subsidize care ${ }^{(4)}$. Their use provides scientific character to the profession ${ }^{(9,12)}$, strengthens the care process, and favors actions directed at the human being, within a certain context, contributing to restore their health.

For decades, there has been an understanding of the importance of different forms of nursing knowledge for the desired integration between theory, research, and practice ${ }^{(2,9)}$. Associating them with nursing education gives the students a philosophical point of view of nursing ${ }^{(9)}$, providing their involvement in the field of assistance to promote integration, so that the students' formation maintains a constant relationship of teaching combined with the professional practice environment ${ }^{(18)}$.

The use of the care systematization stood out among the postgraduate students, as they could develop this method in the professional performance with ease. Supported by a theory, students provide the pa- tient with an assistance based on a structured planning, organization, and execution of actions.

Care systematization is an activity that organizes professional work regarding method, personnel, and instruments, enabling the operationalization of the Nursing Process. Its development is built by nurses committed to care, seeking to provide autonomy to the professionals and giving them greater security through registries conducted, besides ensuring the continuity of work $^{(3)}$. Therefore, using the Nursing Care Systematization improves the care provided by the professionals ${ }^{(19)}$.

Although the postgraduate students associated their practice with different theoretical currents, the greatest affinity they reported was with the theory of Basic Human Needs, quoted by half the interviewees. Students' proximity to Horta's theory may be related to the theorist's pioneering in the Nursing Process in Brazil and to the experiences of implementing the Nursing Care Systematization from the 1990s, which contributed to the scientific advancement of nursing practice ${ }^{(3)}$, both in the field of care and of education. This approach of theories guides nurses in the planning of their activities, as reported in another study ${ }^{(6,9)}$.

For the various concepts of nursing, there are different models and theories that can act as the basis for the clinical practice of some nurses. Among nursing theories, some are more used than others, such as the adaptation, self-care, unitary human beings, holistic, and Wanda Horta's Basic Human Needs theory - the most used in Brazil ${ }^{(2)}$.

Results of the present study indicate that most of the students related the practical activities of nursing to a specific theory - in this case, Horta's theory, which presents a care plan and, more than a model, is a philosophy that can correlate theory and practice and assist in the improvement of nurses' actions.

It is also worth highlighting the scarce scientific production concerning this subject, focused on the teaching of theories, which could contribute to our findings, instead of studies that only address specific 
theories. This discussion resumes the need to broaden and emphasize theories in nursing curricula, both at undergraduate and postgraduate level.

In the perception of the postgraduate students, despite the limitations of this subject in their formation, the teaching of nursing theories in undergraduate studies and its deepening in the postgraduate are essential conditions for recognizing the profession and valuing the scientific knowledge for the know how to know, know how to do, and know how to be a nurse and its inclusion in social practice.

\section{Conclusion}

There has been a limited contact with theories in undergraduate studies. The resumption of this thematic at the postgraduate level is indicated as opportune. In the perception of the postgraduate students, the knowledge of the nursing theories allows the professional to extract its essence, to scientifically strengthen their practice, thus recognizing them as work guidelines.

\section{Collaborations}

Silva PLAR and Pelloso SM contributed to the conception and design, data analysis and interpretation, and drafting of the article. Merino MFGL and Higarashi IH collaborated with the drafting of the article and relevant critical review of intellectual content. Carvalho MDB and Baldissera VDA contributed to the drafting of the article and relevant critical review of intellectual content. All authors contributed to the approval of the final version to be published.

\section{References}

1. Alligood, MR. Nursing Theory: utilization \& application. St. Louis: Missouri; 2013.

2. McEwen M, Wills EM. Bases teóricas de enfermagem. Artmed: Porto Alegre; 2015.
3. Soares MI, Resck ZMR, Terra FS, Camelo SHH. Systematization of nursing care: challenges and features to nurses in the care management. Esc Anna Nery. 2015; 19(1):47-53. doi: http://dx.doi. org/10.5935/1414-8145.20150007

4. Lima JVF, Guedes MVC, Silva LF, Freitas MC, Fialho AVM. Utilidade da teoria do conforto para o cuidado clínico de enfermagem à puérpera: análise crítica. Rev Gaúcha Enferm. 2016; 37(4):e65022. doi:http://dx.doi.org/10.1590/19831447.2016.04.65022

5. Savieto RM, Leão ER. Assistência em Enfermagem e Jean Watson: uma reflexão sobre a empatia. Esc Anna Nery. 2016; 20(1):198-202. doi: http:// dx.doi.org/10.5935/1414-8145.20160026

6. Porto AR, Thofehrn MB, Pai DD, Amestoy SC, Joner LR, Palma JS. Nursing theories and models that enhance professional practice. Rev Pesqui Cuid Fundam Online [Internet]. 2013 [cited 2018 Mar 15]; 5(5):155-61. Available from: http://www.lume.ufrgs.br/ bitstream/handle/10183/140201/000914111. pdf?sequence $=1$

7. González MA, Castelló BM, Font CM. The identity of the nursing academic: between education and research. Texto Contexto Enferm. 2014; 23(2):2419.doi:http://dx.doi.org/10.1590/010407072014001640013

8. Queirós PJP, Vidinha TSS, Filho AJA. Autocuidado: o contributo teórico de Orem para a disciplina e profissão de Enfermagem. Rev Enf Ref [Internet]. 2014 [citado 2018 mar. 15]; IV(3):157-64. Disponível em: http://www.scielo.mec.pt/pdf/ ref/vserIVn3/serIVn3a18.pdf

9. Mete S, Gokçe İsbir G. Using a nursing theory or a model in nursing $\mathrm{PhD}$ dissertations: a qualitative study from Turkey. Int J Nurs Knowl. 2015; 26(2):62-72. doi: http://dx.doi. org/10.1111/2047-3095.12036

10. Henckemaier L, Siewert JS, Tonnera LCJ, Alvarez AM, Meirelles BHS, Nitschke RG. Cuidado transcultural de Leininger na perspectiva dos programas de pós-graduação em enfermagem: revisão integrativa. Rev Ciênc Saúde [Internet]. 2014 [citado 2018 mar. 14]; 7(2):85-91. Disponível em:http://revistaseletronicas.pucrs.br/ojs/ index.php/faenfi/article/view/15722/11848 
11. Minayo M. O desafio do conhecimento: pesquisa qualitativa em saúde. São Paulo: Hucitec; 2014.

12. Dourado SBPB, Bezerra CF, Anjos CCN. Conhecimentos e aplicabilidade das teorias de enfermagem pelos acadêmicos. Rev Enferm UFSM. 2014; 4(2):284-91. doi: http://dx.doi. org/10.5902/217976929931

13. Cunha CMSLM, Macedo APMC, Vieira IGFF. Perceções dos estudantes de enfermagem sobre os processos formativos em contexto de ensino clínico. Rev Enf Ref [Internet]. 2017 [citado 2018 mar. 15]; IV(12):65-74. Disponível em: http://www.scielo.mec.pt/pdf/ref/vserIVn12/ serIVn12a08.pdf

14. Hirsch CD, Barlem ELD, Duarte FD, Fornari NC, Silva BR, Nogário ACD. Sociodemographic and academic profile of undergraduate nursing student of the Nursing School/FURG Profile of nursing students. J Nurs Soc Health. 2014; 1(1):138. doi: http://dx.doi.org/10.15696/2358-9884/ jonse.v1n1p13-18
15. Karnick PM. Nursing Theory: The Neglected Essential. Nurs Sci Q. 2013; 26(2):130-1. doi: http://dx.doi.org/10.1177/0894318413477210

16. Jara SF, Lizano PA. Aplicación del proceso de atención de enfermería por estudiantes, un estudio desde la experiencia vivida. Enferm Univ. 2016; 13(4):208-15. doi: http://dx.doi.org/10.1016/j. reu.2016.08.003

17. Yancey NR. Why teach nursing theory? Nurs Sci Q. 2015; 28(4):274-8. doi: http://dx.doi. org/10.1177/0894318415599234

18. Grillo MJC, Silva KL, Sena RR, Tavares TS. A formação do enfermeiro e a necessidade de consolidação do Sistema Nacional de Saúde. Rev Enferm Atenção Saúde [Internet]. 2013 [citado 2018 mar. 24]; 2(2):57-68. Disponível em: http:// seer.uftm.edu.br/revistaeletronica/index.php/ enfer/article/viewFile/402/408

19. Ferreira EB, Pereira MS, Souza ACSS, Almeida CCOF, Taleb AC. Systematization of nursing care in the perspective of professional autonomy. Rev Rene. 2016; 17(1):86-92. doi: http://dx.doi. org/10.15253/2175-6783.2016000100012 